\title{
Leaf morphological traits of Orophea spp. (Annonaceae): Living collections of Purwodadi Botanic Gardens, East Java, Indonesia
}

\author{
DEWI AYU LESTARI", ABBAN PUTRI FIQA ${ }^{\natural », ~ I L H A M ~ K U R N I A ~ A B Y W I J A Y A ~}$ \\ Purwodadi Botanic Gardens, Research Center for Plant Conservation and Botanic Gardesn, Indonesian Institute of Sciences. Jl. Surabaya-Malang Km 65, \\ Purwodadi, Pasuruan 67163, East Java, Indonesia. Tel./fax.: +62-343-615033, ”email: chunyang.dee@ gmail.com; " abbanpf@ gmail.com; \\ vwilham.abywijaya@gmail.com
}

Manuscript received: 26 March 2021. Revision accepted: 27 May 2021.

\begin{abstract}
Lestari DA, Fiqa AP, Abywijaya IK. 2021. Leaf morphological traits of Orophea spp. (Annonaceae): Living collections of Purwodadi Botanic Gardens, East Java, Indonesia. Biodiversitas 22: 3403-3411. Orophea (Annonaceae) have various benefits and play important roles in lowland forest structures. Due to their importance, various Orophea species currently require identification for research and conservation purposes. One of many important variables for such purpose is leaf morphometrical features. This study aimed to investigate leaf morphometrical variations, measure morphometrical similarities, and identify determinant morphometrical traits for species identification in Orophea spp. As many as 23 living plant specimens of Orophea spp. cultivated in Purwodadi Botanic Gardens (belongs to 4 species: Orophea celebica, O. chlorantha, O. enneandra, O. hexandra and an unidentified Orophea sp.) were observed. Twelve measured leaf morphometrical traits in this study were leaf length and width, petiole length, distance from leaf base to the widest part of the leaf, number of secondary veins, apex and base shape, leaf area, length of leaf margin, length to width ratio, leaf roundness and slimness indices. Data were analyzed using multiple one-way ANOVA, Hierarchical Cluster and Principal Component Analyses from within $\mathrm{R}$. The results highlighted that $O$. hexandra was the most distinguishable species with number of secondary veins, length to width ratio, and leaf slimness as the most distinct characters. The unidentified species of Orophea sp. exhibited morphometrical characters similar to $O$. chlorantha. No distinct leaf morphometrical traits were able to be identified as determinant characters to each species. Thus, suggesting leaf morphological traits analyses to be used only as a supporting component for plant identification, while still paying attention to the plant's generative characters.
\end{abstract}

Keywords: Annonaceae, cluster analyses, identification, leaf morphometry, Orophea

\section{INTRODUCTION}

Annonaceae is one of many prominent families constituting plant communities in tropical lowland ecosystems. Some of its species have been characterizing vegetation structures in lowland forests in Sempu Island (Rindyastuti et al. 2018), Alas Purwo National Park (Darmayanti et al. 2020), and forest areas in East Kalimantan (Fiqa et al. 2019). In addition to their ecological importance, many Annonaceae species have long been recorded to provide edible fruits, biomaterials for medicines, spices, essential oils, and to be cultivated as ornamental plants (Fournier et al. 1999; Chatrou et al. 2012; Frausin et al. 2014; Handayani 2018). Due to their various benefits, species identifications in Annonaceae is pivotal to support conservation and further research on their potential uses.

Purwodadi Botanic Gardens (PBG), as an ex-situ plant conservation institution, has been conserving plant species, collected from various lowland ecosystems in Indonesia, including many species of Annonaceae. Most of the living specimens have been identified up to species level, but some have yet to be identified. So far, the process of identifying species names of Annonaceae has significantly relied on the presence of generative organs, i.e. flowers and fruits (Couvreur et al. 2012; Chatrou et al. 2012). Meanwhile, the majority of Annonaceae living collections in PBG have exhibited evident seasonality in their flowering and fruiting time, and some other specimens have yet to display any of their generative characters (see Lestari and Sofiah 2015; Lestari 2019; Lestari and Fiqa 2020 for details). These issues have led to many difficulties in identifying species in Annonaceae.

Plant phenological cycle includes two phases of plant growth and development, namely generative and vegetative phases. One of many vegetative features that can be potential for species identification is leaf morphology. Leaves, along with their varying characteristics, play essential roles in plant growth and development. Leaves are also very adaptive to changes in the plant's surrounding environments. Plant adaptability can be investigated through their leaf morphological traits and variations (Rodriguez et al. 2016; Bijarpasi et al. 2019; AlcantaraAyala et al. 2020).

Leaf morphological characteristics have been commonly used in systematic studies to distinguish different species of the same taxonomic group (Ye et al. 2020). Ideally, plant species identification requires information on some generative characters. In the presence of only vegetative characters, difficulties in identifying plant species may arise. By using appropriate statistical tools, the collected information on plant's vegetative characters can be used to distinguish species or any taxonomic group. 
One of several Annonaceae genera in PBG whose all living specimens are yet to be identified up to species level is Orophea. This genus belongs to the Miliuseae tribe, the sub-tribe of Malmeoideae. Despite those substantial benefits, species identification in Orophea through morphological observations often relies significantly on the presence of flowers (Keßler 1988; Keßler 1990), in which the inner petals possess connate characteristics and a wide variation of glands (Lestari 2011; Lestari et al. 2017). Contrary, little was known about the characteristics of vegetative features in Orophea, such as leaves, due to morphological similarities among its species. However, leaves can be abundantly available through time and may provide determinant characteristics of species identity (Rosdayanti et al. 2019). Thus, studying variations in leaf morphological characteristics may provide valuable insights about species identification in Orophea.

This study aimed to (i) investigate leaf morphometrical variations in the living specimens of Orophea spp. cultivated in PBG; (ii) investigate leaf morphometrical similarities among specimens and among species to identify which species could the unidentified specimens of Orophea sp. closely similar to; and (iii) identify leaf morphometrical variables that could be the most significant for species identification in Orophea. Results from this study were hoped to facilitate reliable species identifications in PBG to further support conservation, environmental education, and potential future research. Furthermore, this study may also be used as a reference to identify living or herbarium specimens of Orophea spp. that are yet to be identified.

\section{MATERIALS AND METHODS}

\section{Study area}

This research was conducted in March-May 2020 in the garden's section of Orophea living collections cultivated ex-situ in Purwodadi Botanic Gardens-LIPI, Pasuruan, East
Java. Four Orophea species were observed as the study materials; namely $O$. celebica, $O$. chlorantha, $O$. enneandra, $O$. hexandra, and an unidentified species, namely Orophea sp. The observed plants for each species were 1 specimen $(O$. celebica $), 8$ specimens $(O$. enneandra), 2 specimens ( $O$. hexandra), 9 specimens $(O$. chlorantha), and 3 specimens (Orophea sp.) from four management blocks (i.e., XVIII.C., XVIII.D., XVIII.E. and XIX.B.I (Figures 1 and 2; Table 1)).

\section{Procedures}

Plant materials used were mature leaves in perfect condition (having no hole nor any deformed part). For each specimen, five leaves were sampled incorporating petiole and lamina of the leaf (Lestari and Hikmah 2012). A total of twelve leaf morphological variables were observed and measured (Table 2). Nine variables were observed and measured directly, while three others were derived from a calculation. The three derived measures (i.e., length to width ratio, roundness, and slimness) referred to previous research of $\mathrm{Wu}$ et al. (2007) and Varsamis et al. (2020) with few modifications. A chart of the measured variables is shown in Figure 3.

\section{Data analysis}

Variations in leaf morphometries were analysed using multiple one-way ANOVA and Tukey's significant difference test. Morphometrical similarities between specimens and between species were analyzed using Hierarchical Cluster Analyses with Euclidian distances and the average linkage method. Determinant morphometrical variables to each Orophea species were investigated using Principal Component Analysis (PCA). For the last two multivariate analyses, all variables were standardized to have a mean of zero and a standard deviation of one $(\mathrm{Z}$ scores). All analyses in this study were run from within $\mathrm{R}$ program ver. 4.05 (R Core team 2021).
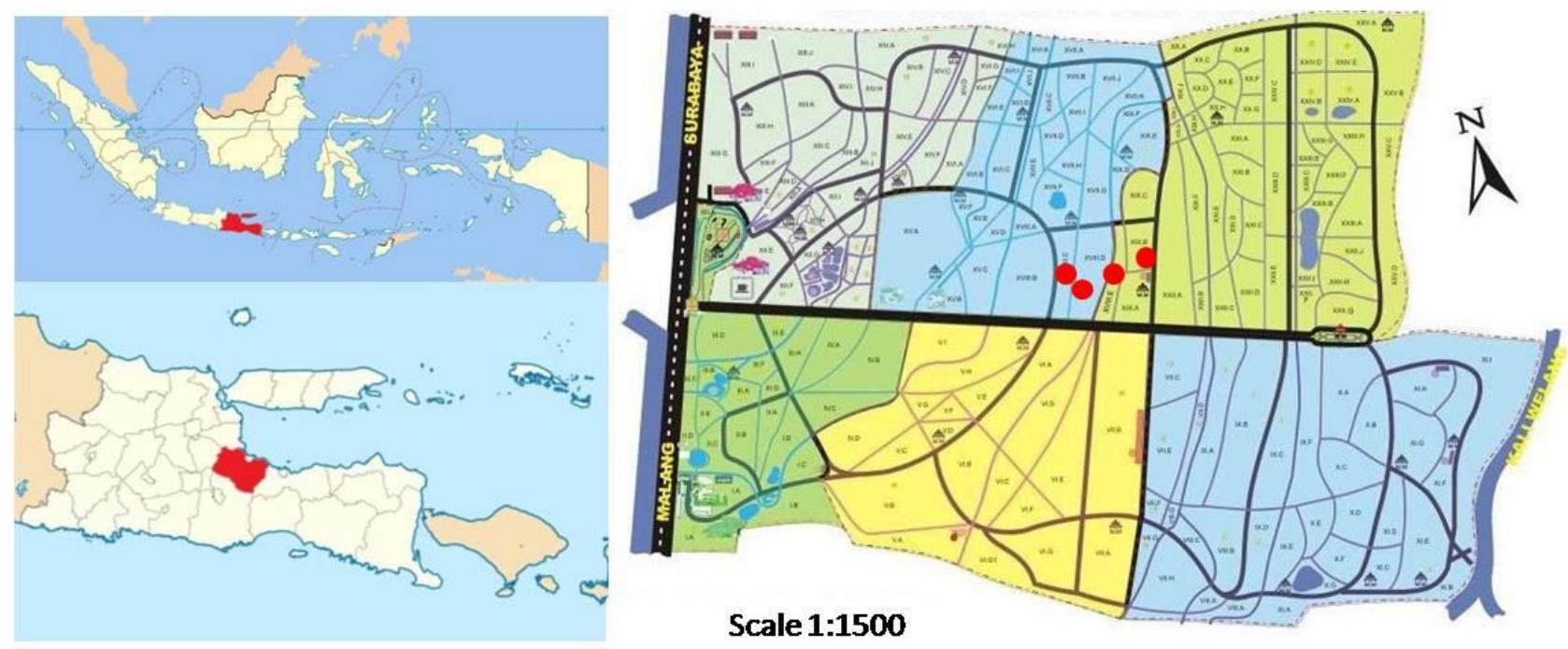

Figure 1. Study area in Purwodadi Botanic Gardens, Pasuruan, East Java, Indonesia (red circle symbol is observation location) 


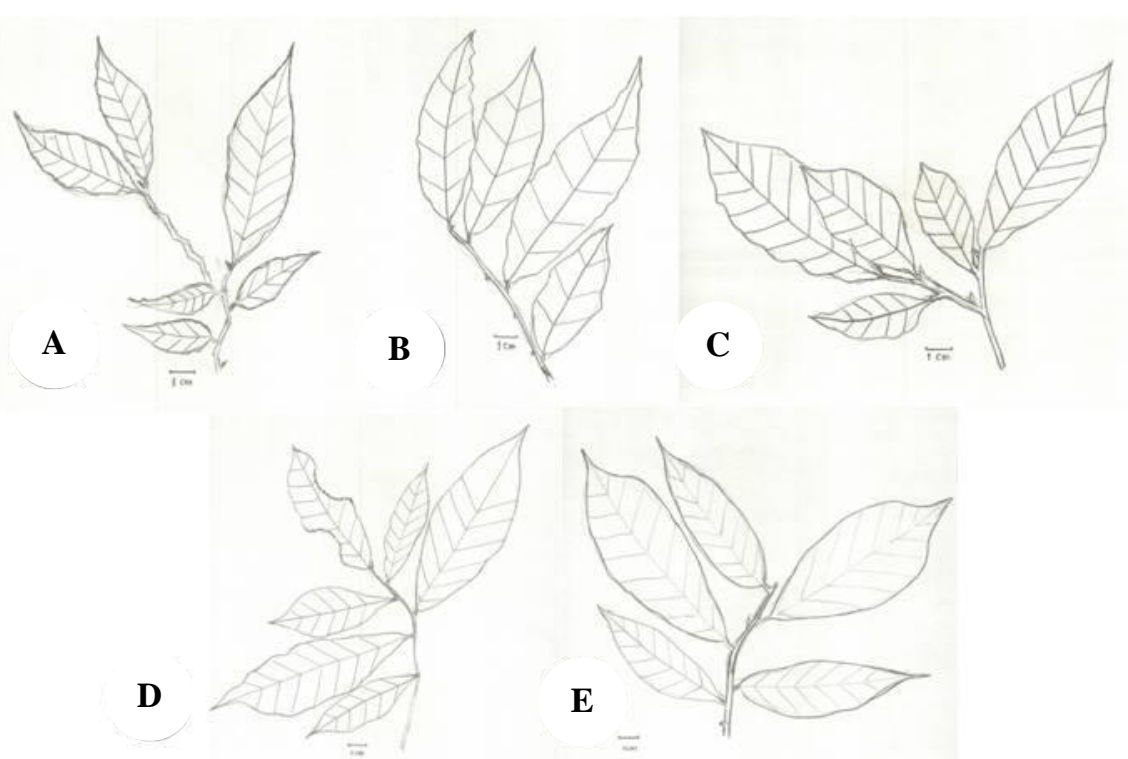

Figure 2. Leaves illustration of Orophea spp. in Purwodadi Botanic Gardens, East Java, Indonesia; A. Orophea celebica, B. Orophea chlorantha, C. Orophea enneandra, D. Orophea hexandra and E. Orophea sp. (drawn by APF)

Table 1. Plant materials of Orophea spp.

\begin{tabular}{lll}
\hline \multicolumn{1}{c}{ Species } & \multicolumn{1}{c}{ Location } & \multicolumn{1}{c}{ Origin } \\
\hline Orophea celebica (Blume) Zoll. & XVIII.D.4 & Buru Island, Moluccas \\
Orophea enneandra Blume & XVIII.C.25-a & Meru Betiri National Park, East Java \\
& XVIII.C.26 & Malang, East Java \\
& XVIII.C.76 & Sempu Island, East Java \\
& XVIII.C.77 & Sempu Island, East Java \\
& XVIII.E.3 & Lumajang, East Java \\
Orophea hexandra Blume & XIX.B.I.93-a & Bawean Island, East Java \\
Orophea chlorantha P.J.A. Kessler & XVIII.E.8-a & Banyuwangi, East Java \\
& XVIII.E.43-a & Baluran National Park, East Java \\
& XVIII.E.44-abc & Baluran National Park, East Java \\
Orophea sp. & XIX.B.I.62-ab & Alas Purwo National Park, East Java \\
& XVIII.E.64-ab & Lejja Nature Tourism Park, South Sulawesi \\
\hline
\end{tabular}

Table 2. Twelve leaf morphometrical variables observed in this study

\begin{tabular}{|c|c|c|}
\hline Abbr. & Variables & Data collection \\
\hline Lgth & Leaf length & (direct measurement) \\
\hline Wdth & Leaf width & (direct measurement) \\
\hline Ptle & Petiole length & (direct measurement) \\
\hline$B s-W d$ & Distance from leaf base to the widest part of the leaf & (direct measurement) \\
\hline Vein & Number of secondary veins & (direct count) \\
\hline Area & Leaf area & (direct measurement) \\
\hline Mrgn & Length of leaf margin & (direct measurement) \\
\hline$L: W$ & Ratio of leaf length to leaf width & $=$ Lgth $/$ Wdth \\
\hline Round & $\begin{array}{l}\text { Roundness; } \\
\text { (a measure of how round the leaf shape is) }\end{array}$ & $\begin{aligned}= & (4 \times \pi \times \text { Area }) /(\text { Mrgn })^{2} \\
& (* L / \mathrm{W} \text { value of equal one means a perfect round shape })\end{aligned}$ \\
\hline \multirow[t]{2}{*}{ Slim } & Slimness; & $=\operatorname{Mrgn} /$ Wdth \\
\hline & (a measure of how slender the leaf shape is) & (*higher values indicate long and slender leaves) \\
\hline \multirow[t]{2}{*}{$\begin{array}{l}\text { Apex } \\
\text { Base }\end{array}$} & $\begin{array}{l}\text { Apex shape } \\
\text { Base shape }\end{array}$ & $\begin{array}{l}\text { Tip shape scoring: } \\
\text { (*the higher the score, the pointier the leaf tip is) }\end{array}$ \\
\hline & & $\begin{array}{ll}1=\text { rounded } & \\
2=\text { cuneate } & \text { (wedge-shaped) } \\
3=\text { acute } & \text { (sharp) } \\
4=\text { asymmetric } & \text { (irregular) } \\
5=\text { acuminate } & \text { (long-tapering) }\end{array}$ \\
\hline
\end{tabular}




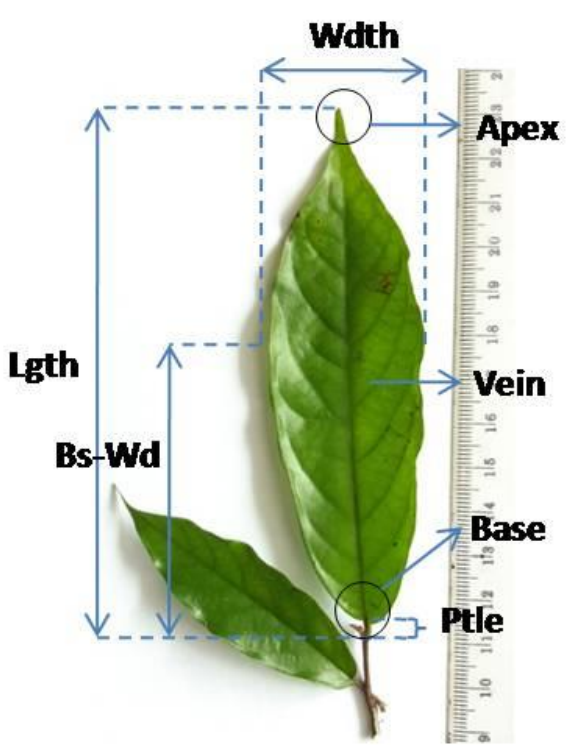

Figure 3. The measured variables of leaf morphological traits of Orophea spp.

\section{RESULTS AND DISCUSSION}

\section{Variations in twelve leaf morphometrical traits of Orophea spp.}

The multiple one-way ANOVA and Tukey's test results informed varying morphometrical characters in Orophea's leaves (Figure 4). All five species were observed to be not significantly different in leaf length $($ Lgth), area $($ Area $)$, and base to the widest part distance $(B s-W d)$. Meanwhile, four other characters, i.e. base shape (Base), length to width ratio $(L: W)$, roundness (Round) and slimness (Slim) indices, showed only one significantly different species in each of these morphometries. There were no substantially distinct species, except for $O$. hexandra that exhibited significantly different morphometries in length to width ratio $(L: W)$, roundness (Round), slimness (Slim), and number of secondary veins (Vein) than the rest of the species.

\section{Grouping of Orophea specimens and species based on morphometrical similarities}

Heatmap hierarchical clustering revealed three groups on both specimens and leaf morphometrical traits that determined the grouping of Orophea specimens (Figure 5). The first group of leaf traits comprised of base shape (Base) and roundness (Round). The second group comprised of petiole length (Ptle), leaf width (Wdth), distance from base to the widest part of the leaf $(B s-W d)$, leaf area (Area), leaf length (Lgth) and length of leaf margin (Mrgn), while the third group comprised of apex shape (Apex), number of secondary veins (Vein), length to width ratio $(L: W)$, and slimness (Slim).

The hierarchical clustering of Orophea also highlighted three groups of specimens. The first specimen group is the largest cluster comprised of twelve specimens that belonged to four species (O. celebica, O. enneandra, $O$. chlorantha and Orophea sp.). This cluster of specimens possessed substantially smaller sizes of the second leaf traits group (Ptle, Wdth, Bs-Wd, Area, Lgth, and Mrgn) but average to small sizes in other traits. The second-largest group was the third cluster that comprised nine specimens (belonged to two species, namely $O$. enneandra and $O$. chlorantha). These specimens possessed substantially larger sizes of the second leaf traits group and large to average sizes in other traits. The heatmap plot clearly distinguished two specimens of $O$. hexandra from all other specimens in the second specimen cluster. This result suggests that $O$. hexandra might possess distinct leaf morphometrical characters from the four other Orophea species.

On the other hand, hierarchical cluster analysis of Orophea species based on leaf morphometrical traits revealed different clustering of leaf traits that determined species similarity. The heatmap plot distinguished $O$. celebica to be different from other species, indicated by its smallest size in most leaf morphometrical traits but average in only leaf roundness (Figure 6). The second most distinguishable species was $O$. hexandra, which leaf secondary veins, length to width ratio, and slimness were the highest among all. On the contrary, the heatmap clustering distinguished $O$. enneandra by its comparatively large leaf area, long margin, width, length, distance from base to the widest part of the leaf, and also sharp leaf base and apex. The hierarchical clustering of Orophea species highlighted the unidentified Orophea sp. to be closest to $O$. clorantha based on their leaf morphometrical similarity.

\section{Determinant leaf morphometrical traits for species identification in Orophea spp.}

Five morphometrical traits were omitted from the PCA to avoid multicollinearity among variables. Leaf roundness and slimness were excluded due to their high correlation with length to width ratio. Leaf area, margin, and distance from base to widest part were also excluded from the analysis due to their high correlation with leaf length and width. Seven leaf morphometrical traits that were independent of each other were then analyzed using PCA (Figure 7). Despite its relatively high $R^{2}$ correlation coefficient, the variable of leaf length was still retained for the PCA due to its morphological significance in plant species generally. The Principal Component Analysis failed to discriminate five Orophea species using seven independent leaf morphometrical characters (Figure 8), due to their remarkably high morphometrical variations. It was also difficult to identify which morphometrical character was determinant to which species identity from the PCA biplot (Figure 8.A). There was a small remark to the $O$. hexandra which morphometrical variations seemed to be correlated with leaf apex shape and length to width ratio of the leaf, similar to Tukey's test and Heatmap clustering results. However, all species generally had a substantial proportion of their data points scattered towards the opposite directions of all morphometrical trait arrows. There were seven PCs that resulted from the Principal Component Analysis, with the first and second PCs explained $60.80 \%$ of variances in the data altogether (Figure 8). 

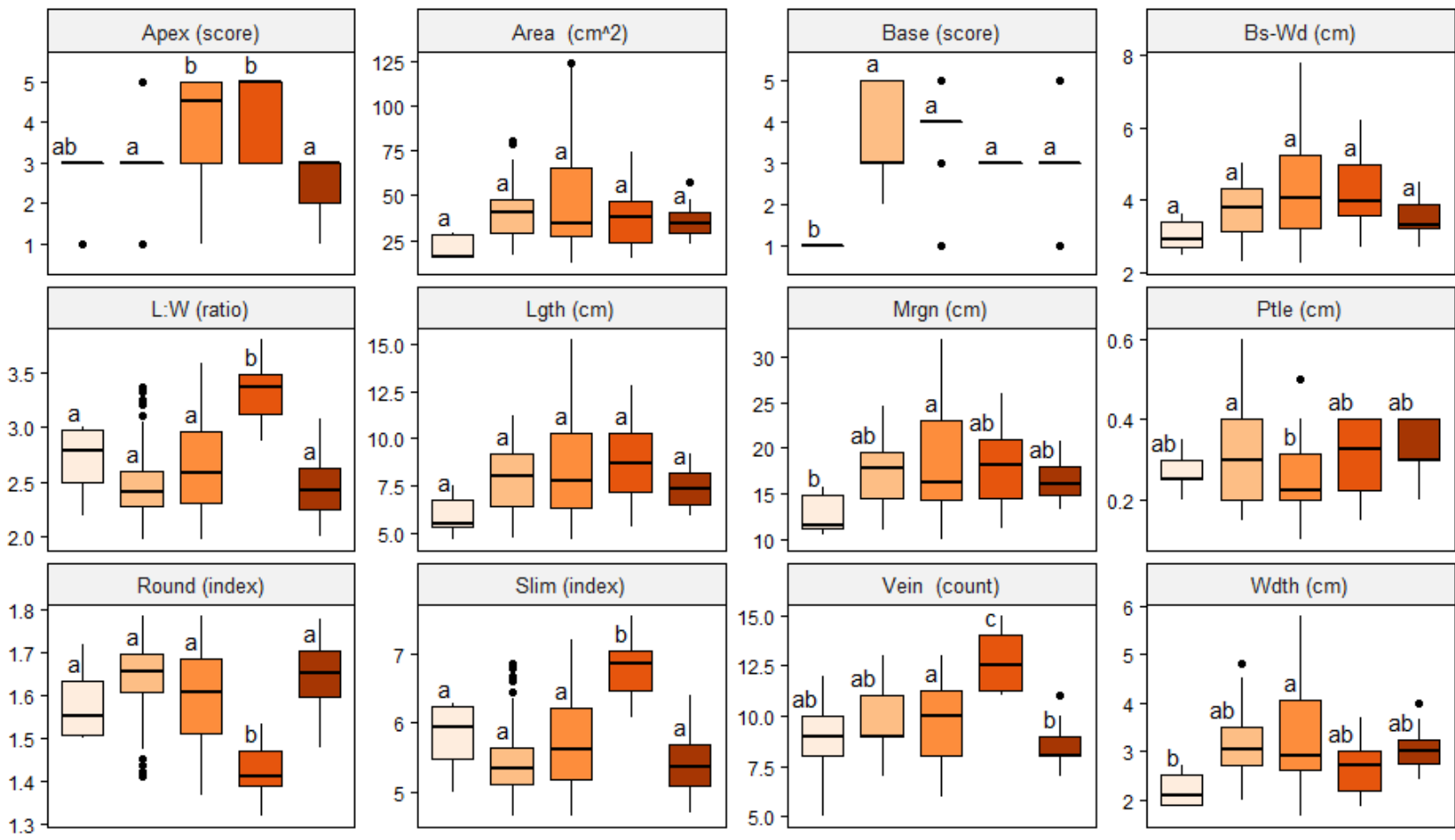

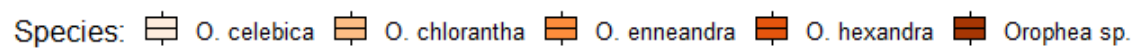

Figure 4. Box plots of twelve leaf morphometrical traits of Orophea spp. in Purwodadi Botanic Gardens, East Java, Indonesia; lower and upper whiskers indicate $\mathrm{Q}_{1}$ and $\mathrm{Q}_{4}$, while lower and upper colored bars indicate $\mathrm{Q}_{2}$ and $\mathrm{Q}_{3}$, horizontal lines in the bars denote median and black points indicate outliers; letters: a, ab, b, c denote Tukey's test results, in which species sharing the same letter don't have significantly different leaf morphometry

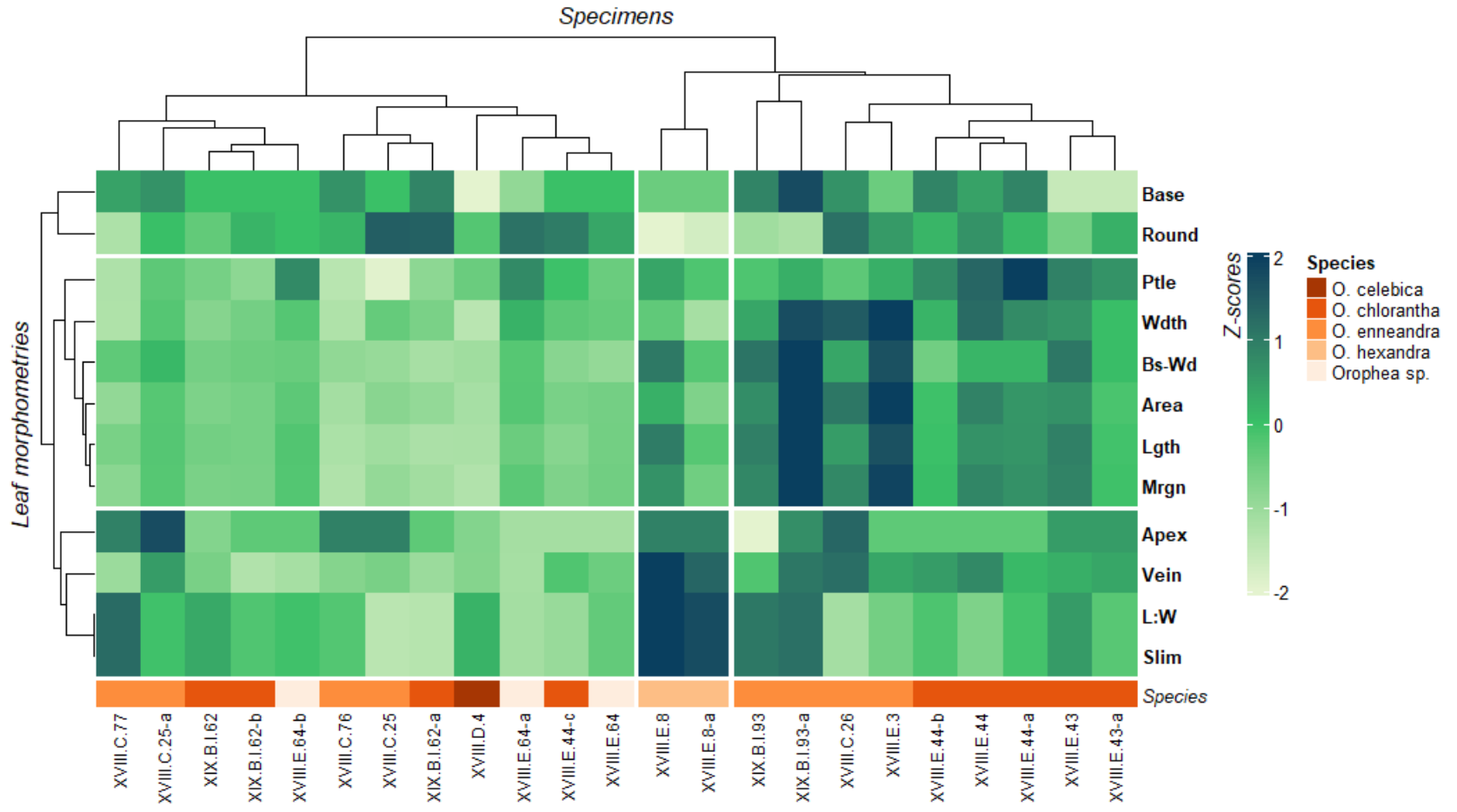

Figure 5. Heatmap hierarchical clustering of 23 Orophea specimens and twelve leaf morphometrical characters 


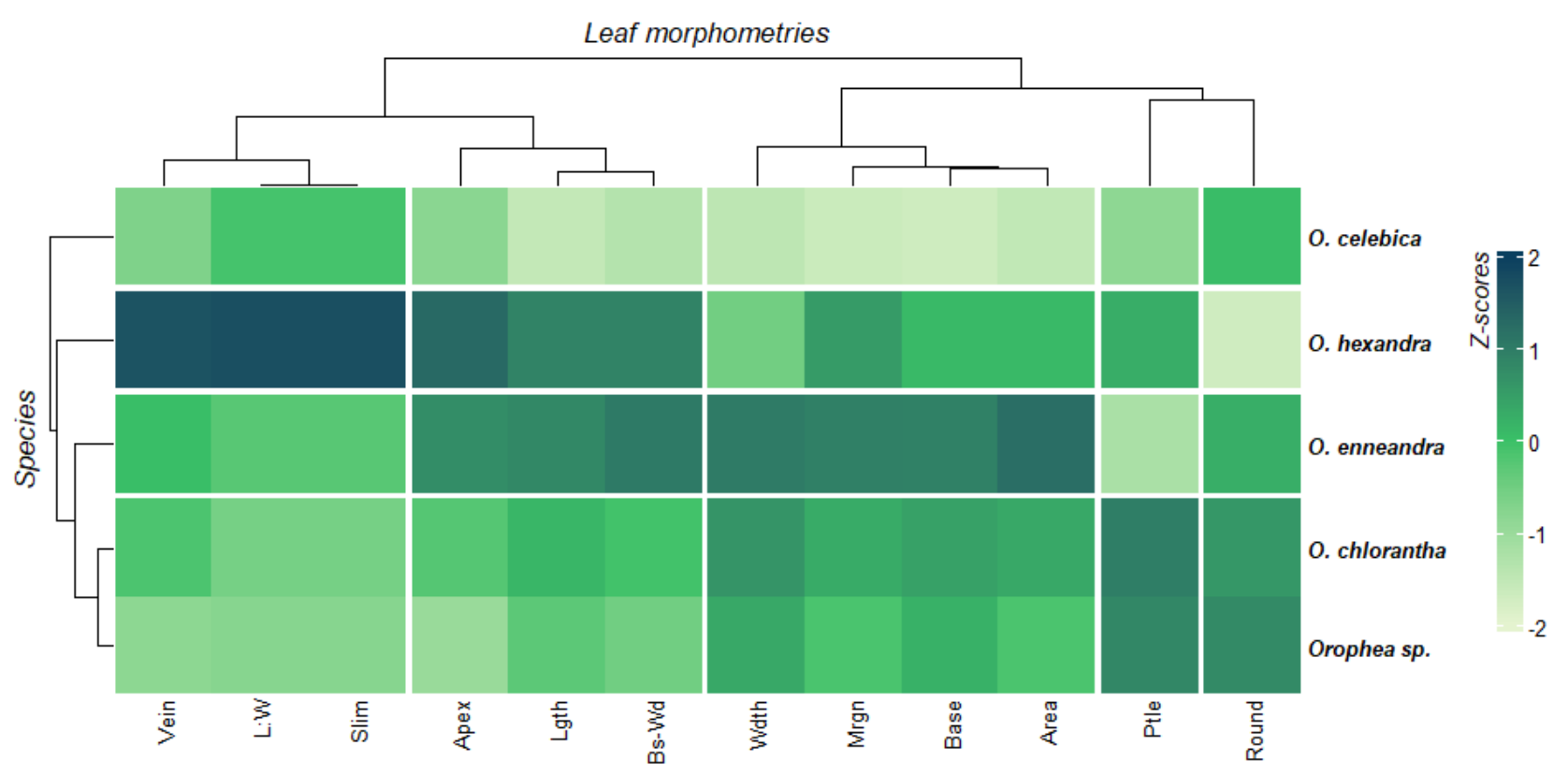

Figure 6. Heatmap hierarchical clustering of 5 Orophea species and twelve leaf morphometrical characters

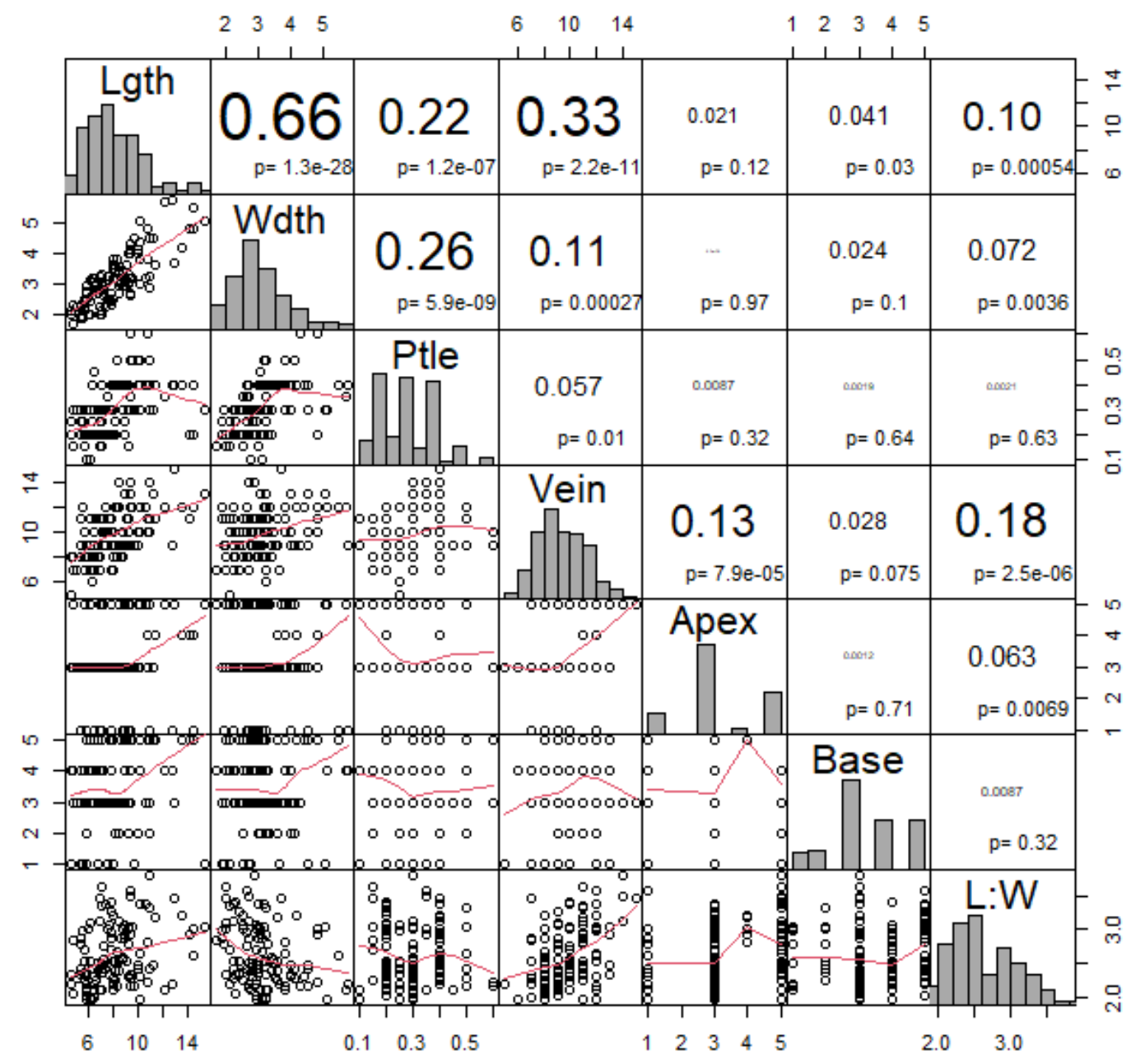

Figure 7. Pairwise correlation plots of seven independent leaf morphometrical parameters for PCA; lower panel indicates each pair of leaf traits' scatter plots with red lines denote local polynomial regressions using Locally Weight Scatter plot Smoothing (LOWESS); diagonal panel indicates each leaf trait's density bar plot; upper panel indicates $R^{2}$ of Pearson correlation coefficient with font size scaled to the $\mathrm{R}^{2}$ value in the upper text and $p$-value of statistical significance in the lower text. 


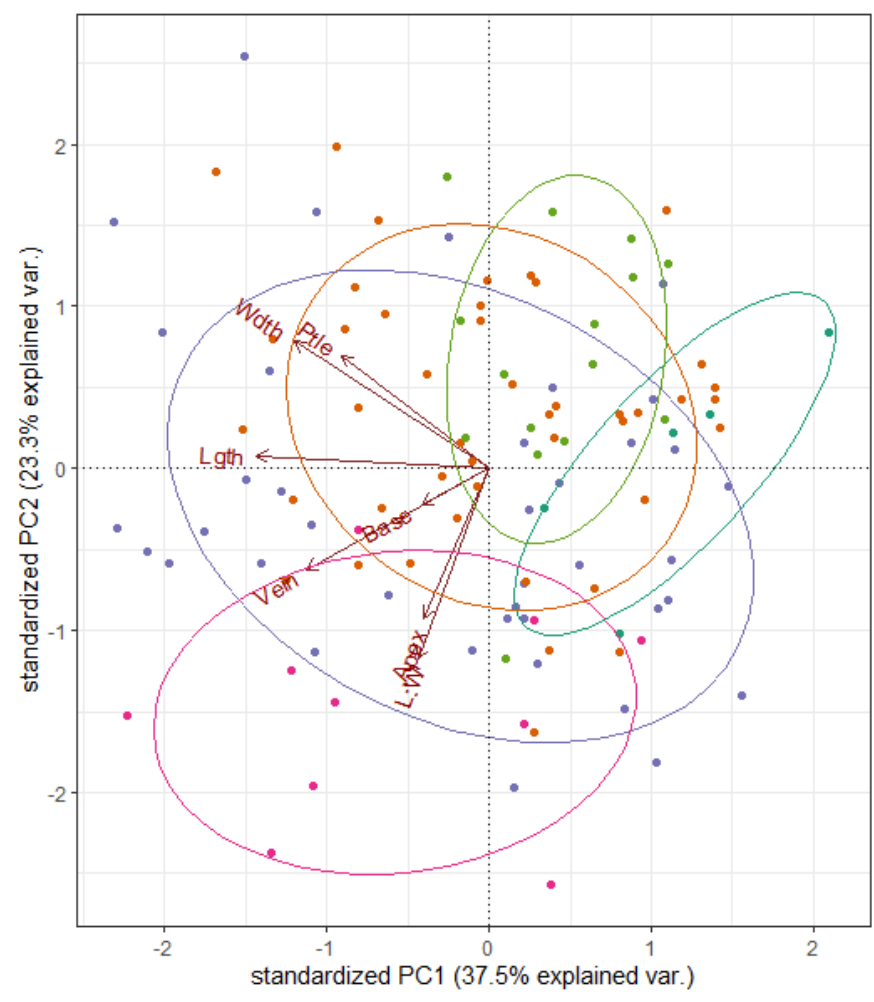

A

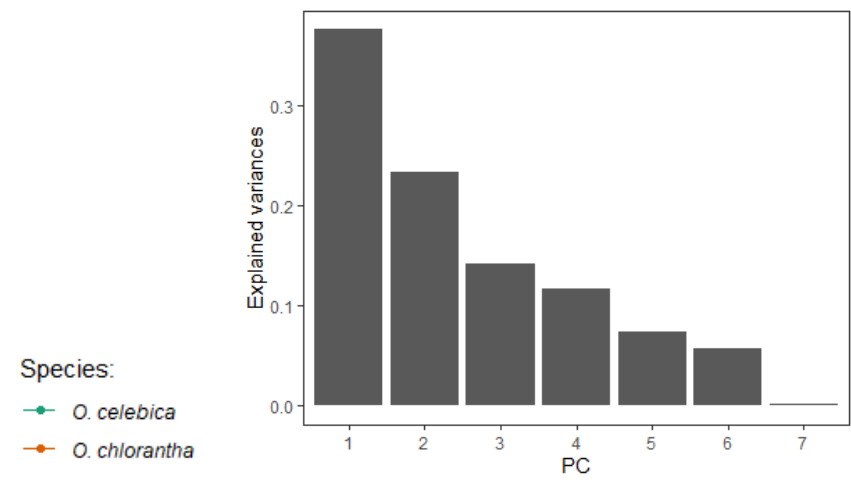

$\rightarrow$ O. enneandra

$\rightarrow$ O. hexandra

$\rightarrow$ Orophea sp.

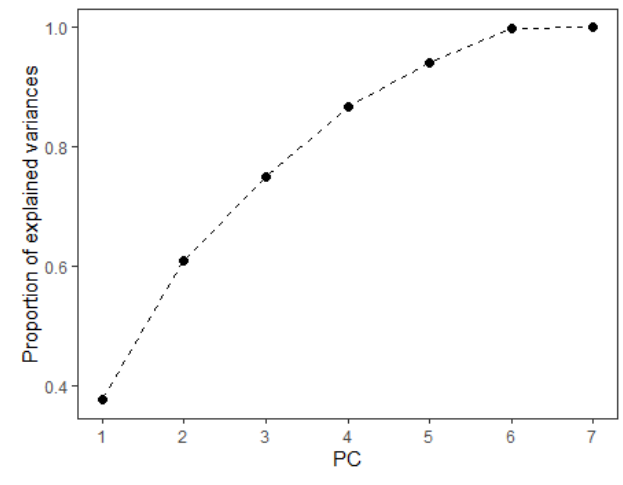

C

Figure 8. PCA results; A) PCA biplot containing information on loadings (leaf morphometrical traits arrow) and scores (data points with colors representing each Orophea species), ellipses explain $68 \%$ probability of normal data distribution, all data were standardized; B) Scree plot of eigenvalue denoting the explained variance of each Principal Component (PC); C) Line plot indicating the cumulative proportion of explained variances of each PC.

\section{Discussion}

Many species of Orophea possess ecological significance (Wardah et al. 2012) as well as remarkable medicinal properties (Lorenzo et al. 2020) and great potentials as ornamental plants (Hidayat and Kurnita 2018). Thus, species identification of Orophea in PBG is crucial for their conservation and further research. Heatmap hierarchical clustering from this study highlighted the unidentified Orophea sp. to be closest to O. chlorantha based on all twelve leaf morphometrical characters. However, this result does not necessarily mean both of them to be the same species. Further investigation might be required.

The heatmap clustering also revealed that $O$. celebica exhibited distinguish morphometrical characteristics from other species (Figures 6, 8.A), although the number of samples observed was relatively small. The distinct characters of $O$. celebica could be resulted from habitat unsuitability, since the specimens were collected from Moluccas, while most Orophea specimens originated from East Java. Variations in leaf morphological traits were also known to be influenced by habitat (Sun et al. 2016). In some taxa, one species can be distinguished from the others based on variations in leaf morphology alone, one of which is the genus of Uvaria (Meade and Parnell 2003). However, due to the high leaf variation in the genus of Orophea, it is difficult to identify up to species level. The limited number of specimens collected in PBG also generated some obstacles, such as limiting the observable samples.

Quantitative measurements of leaf morphological characters through the traditional morphometric approach have been known to be useful for grouping and distinguishing different plant species (Patil and Bhagat 2016), with a certain confidence level. This approach can be an effective method and also statistically powerful (Viscosi and Cardini 2011). Quantitative measures of plant's vegetative characters, combined with multivariate statistical analyses, can be a useful tool for grouping specific plant taxa (Jin et al. 2015, Jimenez-Mejias et al. 2017; Chuanromance et al. 2019). However, results from this study suggest that those findings were not entirely applicable for Orophea spp.

The PCA results of this study (Figure 8.A) failed to confidently discriminate five Orophea species due to their high variability in leaf morphometries. The majority of all five species data points were scattered towards the opposite directions of leaf morphometrical variable arrows, suggesting the possibility of factors determinant for species identification other than leaf morphometries exist. Such factor could be the plant's generative features, since plant species identification generally requires both vegetative and generative characters to be present. This study highlighted the importance of those generative characters 
in the identification of Orophea spp., except for $O$. hexandra which leaf morphometries were distinguishable through statistical multivariate analyses. The leaves of $O$. hexandra were recorded to exhibit elongated or oval leaf shapes, rounded or wedge-shaped leaf base, tapered leaf apex, with 7 to 9 pairs of secondary leaf veins, and a leaf length of 4-22 cm, with 2-8 cm in width (Kessler 1988; van Steenis 2006). Nevertheless, identification of Orophea spp. still requires generative characters such as flowers and stamen (Turner 2018), while the vegetative characters can be a supporting component in the identification process.

The leaf qualitative morphological characters could also be an important factor for species identification in Orophea spp., other than their generative characters. Thus, classifying species using leaf morphometrical traits only, might not be sufficient, unless other qualitative leaf traits such as leaf colors and textures were also incorporated (Caglayan et al. 2013). The leaf color spectrum, for instance, can be functional to distinguish different families or different species within a family (Bahrami and Mobasheri 2020). In the case of Asian Uvaria (Annonaceae) species, discriminant analyses using patterns in leaf shapes only yielded low classification accuracy (Meade and Parnell 2003). Since leaves from different plants usually exhibit different or unique features (e.g., shape, vein patterns, texture, color, and margin), plant identification should incorporate these other useful traits as well (Agrawal et al. 2018).

Many studies on leaf morphology of Annonaceae were aimed to re-classifying the taxonomic group. Chatrou's (1997) using leaf shape characters for elucidating taxonomic relationships in Annonaceae. In that study, the characters of length to width ratio and base shape were the two most important characters to cluster the group. In another different case, the leaf length and apex shape could discriminate the species of Annona reticulata in Colombia (Castaneda-Garzon et al. 2016). However, general descriptions of leaf morphology especially for venation patterns and anatomy of annonaceous leaf type were still considered poorly described (van Setten and KoekNoorman 1992).

Basically, research on species identification using leaf morphology is still considered rare, although leaves are relatively abundant through time (Krieger 2010; Lu et al. 2012). This study highlighted the functionality of leaf morphometrical traits combined with appropriate statistical tools for investigating variations, measuring similarity, and distinguishing patterns in leaf morphometries of Orophea spp. Seven leaf morphometrical traits (i.e., leaf length, leaf width, petiole length, number of secondary leaf veins, apex and base shape, and leaf length to width ratio) were considerably independent to each other. Those seven leaf traits, which were mostly from direct observation and measurements, reflected the leaf parameters commonly used in conventional plant taxonomy. Based on this study, leaf morphometrical analyses can still be a potential component to support identification of Orophea species using plant's generative features and any available qualitative leaf morphological characters.

\section{ACKNOWLEDGEMENTS}

The authors greatly acknowledge the authorities of Purwodadi Botanic Gardens for providing the plant materials for this study. For author's contribution, DAL contributed to the conceptualization of the research, designing experiments, conducting field observations, collecting the data, and writing the manuscript. APF and IKA contributed to the data analysis with results interpretation and writing the manuscript. $\mathrm{R}$ codes for data analyses were prepared by IKA.

\section{REFERENCES}

Agrawal S, Jalal AS, Khan MA. 2018. Plant Identification using Leaf Image Analysis. Proceeding of 3rd International Conference on Internet of Things and Connected Technologies, Malaysia National Institute of Technology, Jaipur, India, 26-27 March 2018.

Alcantara-Ayala O, Oyama K, Rios-Munoz CA, Rivas G, RamirezBarahona S, Luna-Vega I. 2020. Morphological variation of leaf traits in the Ternstroemia lineata species complex (Ericales: Penthaphylacaceae) in response to geographic and climatic variation. Peer J 8: e8307. DOI: $10.7717 /$ peerj.8307.

Bahrami M, Mobasheri MR. 2020. Plant species determination by coding leaf reflectance spectrum and its derivates. Eur J Remote Sens 53 (1): 258-273. DOI: 10.1080/22797254.2020.1816501.

Bijarpasi MM, Shahraji TR, Lahiji HS. 2019. Genetic variability and heritability of some morphological and physiological traits in Fagus orientalis Lipsky along an elevation gradient in Hyrcanian forests. Folia Oecologica 46: 45-53. DOI: 10.2478/foecol-2019-0007.

Caglayan A, Guclu O, Can AB. 2013. A plant recognition approach using shape and color features in leaf images. Proceeding of International Conference on Image Analysis and Processing, Melbourne, Australia, 15-18 September 2013.

Castaneda-Garzon SL, Ligarreto GAM, Miranda-Lasprilla D. 2016. Morphological evaluation of an in situ collections of species from the Annonaceae family in Colombia. Agron Colomb 34 (2): 131-140. DOI: 10.15446/agron.colomb.v34n2.54527.

Chatrou LW, Erkens RHJ, Richardson JE, Saunders RMK, Fay MF. 2012. Editorial: The natural history of Annonaceae. Bot J Linn Soc 169: 14. DOI: $10.1111 / \mathrm{j} .1095-8339.2012 .01242 . x$.

Chatrou L. 1997. Studies in Annonaceae XXVII. Macromorphological variation of recent invaders in northern Central America: the case of Malmea (Annonaceae). Am J Bot 84: 861-869.

Chuanromance TS, Cohen JI, Ryan GI. 2019. MASS: an integrative software program for morphometric analyses of leaves. Appl Plant Sci 7 (9): e11288. DOI: 10.1002/aps3.11288.

Couvreur TLP, Maas PJM, Meinke S, Johnson DM, Keßler PJA. 2012. Keys to the genus of Annonaceae. Bot J Linn Soc 169: 74-83. DOI: 10.1111/j.1095-8339.2012.01230.x.

Darmayanti AS, Lestari DA, Firdiana ER. 2020. Seed exploration and conservation in Alas Purwo National Park. Biosci Res 17 (4): 28252835.

Fiqa AP, Fauziah, Lestari DA, Budiharta S. 2019. The importance of insitu conservation area in mining concession in preserving diversity, threatened and potential floras in East Kalimantan, Indonesia. Biodiversitas 20 (1): 198-210. DOI: 10.13057/biodiv/d200123.

Fournier G, Leboeuf M, Cave A. 2011. Annonaceae Essential Oils: A Review. J Essent Oil Res 11 (2): 131-142. DOI: 10.1080/10412905.1999.9701092.

Frausin G, Lima RBS, Hidalgo ADF, Maas P, Pohlit AM. 2014. Plants of the Annonaceae traditionally used as antimalarials: a review. Rev Bras Frut 36: 315-337.

Handayani T. 2018. Diversity, potential and conservation of Annonaceae in Bogor Botanic Gardens, Indonesia. Biodiversitas 19 (2): 591-603. DOI: 10.13057/biodiv/d190230.

Hidayat IW, Kurnita NI. 2018. Inventory of Indonesian native montane trees for environmental support and space ornaments in Cibodas Botanical Garden. IOP Conf Ser: Earth Environ Sci 203: 012017.

Jimenez-Mejias P, Cohen JI, Naczi RF. 2017. The study of online digitized specimens revalidates Andersonglossum boreale as a species 
different from A.virginianum (Boraginaceae). Phytotaxa 295 (1): 22 34. DOI: $10.11646 /$ phytotaxa.295.1.2.

Jin T, Hou X, Li P, Zhou F. 2015. A novel method of automatic plant species identification using sparse representation of leaf tooth $\begin{array}{llllll}\text { features. PloS ONE } 10 & \text { (10): } & \text { e0139482. DOI }\end{array}$ 10.1371/journal.pone.0139482.

Keßler PJA. 1988. Revision Der Gattung Orophea Blume (Annonaceae) BLUMEA 33: 1-80.

Keßler PJA. 1990. Studies on the tribe Saccopetaleae (Annonaceae) - II Additions to the genus Orophea Blume. Blumea 34: 505-516.

Krieger JD. 2010. Controlling for Curvature in The Quantification of Leaf Form. In: Elewa AMT (ed.), Morphometric for Nonmorphometricians. Springer, New York.

Lestari DA. 2011. Variation shape and color of gland from genus Orophea (Annonaceae) in Purwodadi Botanical Garden. Proceeding of The International Conference on Basic Science 2011, Galaxy Science Publisher, Malang, 17-18 February 2011. [Indonesian]

Lestari DA. 2019. Evaluation of flowering and fruiting periods of selected Annonaceae species in Purwodadi Botanic Gardens. AIP Conf Proc 2120: 030023. DOI: $10.1063 / 1.5115627$.

Lestari DA, Hikmah LF. 2012. Determination of kinship from genus Annona based on stem, branch and leaves morphometry: collection of Purwodadi Botanic Gardens. Proceeding of Seminar Green Technology 3. Faculty of Sains and Technology, State Islamic University Maulana Malik Ibrahim, Malang, 3 May 2012. [Indonesian]

Lestari DA, Sofiah S. 2015. Flowering and fruiting times on four species of Annona (Annonaceae) in Purwodadi Botanic Gardens. J Trop Life Sci 5 (1): 45-52.

Lestari DA, Fiqa AP. 2020. Environmental factors influence on flowering and fruiting period of selected essential oil plants from Annonaceae. Biodiversitas 21(3): 910-921. DOI: 10.13057/biodiv/d210309.

Lestari DA, Azrianingsih R, Hendrian R. 2017. Taxonomical position of Annonaceae species from East Java, Indonesia: collections of Purwodadi Botanic Gardens based on morphological character Biodiversitas 18 (3): 1067-1076. DOI: 10.13057/biodiv/d180326.

Lorenzo VP, Scotti L, Almeida JRGS, Scotti MT. 2020. Annonaceae family alkaloids as agents against Leishmaniasis: a review and molecular docking evaluation. Curr. Drug Metab. 21(7): 482-492.

Lu H, Jiang W, Ghiassi M, Lee S, Nitin M. 2012. Classification of Camellia (Theaceae) species using leaf architecture variations and pattern recognition techniques. PloS ONE 7 (1): e29704. DOI: 10.1371/journal.pone.0029704.

Meade C, Parnell J. 2003. Multivariate analysis of leaf shape patterns in Asian species of the Uvaria group (Annonaceae). Bot J Linn. Soc 143: 231-242. DOI: 10.1046/j.1095-8339.2003.00223.x.
Patil AA, Bhagat KS. 2016. Plant identification by leaf shape recognition: a review. Intl J Eng Trends Technol 35 (8): 359-361. DOI: 10.14445/22315381/IJETT-V35P273.

R Core Team. 2021. R: A Language and Environment for Statistical Computing. R Foundation for Statistical Computing, Vienna, Austria. https://www.R-project.org/.

Rindyastuti R, Abywijaya IK, Rahadiantoro A, Irawanto R, Nurfadilah S, Siahaan FA, Danarto SA, Hapsari L, Lestari DA, Damaiyani J, Ariyanti EE. 2018. Plant Diversity in Sempu Island with Their Ecosystem. LIPI Press, Jakarta. [Indonesian]

Rodriguez HG, Maiti R, Kumari CA. 2016. Biodiversity of leaf traits in woody plant species in Northeastern Mexico: A synthesis. Forest Res 5(2): 169. DOI: $10.4172 / 2168-9776.1000169$.

Rosdayanti H, Siregar UJ, Siregar, IZ. 2019. Leaf morphology traits of Shorea spp. in ex-situ KHDTK Haurbentes. Media Konservasi 24 (2): 207-215. DOI: 10.29244/medkon.24.2.207-215 [Indonesia]

Sun M, Su T, Zhang SB, Li SF, Anberree-Lebreton J, Zhou ZK. 2016. Variations in leaf morphological traits of Quercus guyavifolia (Fagaceae) were mainly influenced by water and ultraviolet irradiation at high elevations on the Qinghai-Tibet plateau, China. Intl J Agric Biol 18: 266-273. DOI: 10.17957/IJAB/15.0074.

Turner IM. 2018. Annonaceae of the Asia-Pacific region: names, types and distribution. Gardens' Bulletin Singapore 70 (1): 409-744.

Van Setten AK, Koek-Noorman J. 1992. Studies in Annonaceae XVII. Fruits and seeds of Annonaceae. Morphology and its significance for classification and identification. Biblioth Bot 142: 1-101.

Van Steenis CGGJ. 2006. The Mountain Flora of Java. $2^{\text {nd }}$ ed. EJ. Brill, Leiden.

Varsamis G, Karapatzak E, Tseniklidou K, Merou T, Tsiftsis S. 2020. Plant morphological variability at the distribution edges: the case of Dryas octopetala (Rosaceae) in northern Greece. Willdenowia 50 (2): 267-277. DOI: $10.3372 /$ wi.50.50212.

Viscosi V, Cardini A. 2011. Leaf morphology, taxonomy and geometry morphometrics: A simplified protocol for beginners. PloS ONE 6 (10): e25630. DOI: 10.371/journal.pone.0025630.

Wardah, Labiro E, Massiri SD, Sustri, Mursidin. 2012. Key vegetation of anoa habitat in Pangi Binangga Nature Reserve, Central Sulawesi. Wallacea J. Forestry Res 1(1): 1-12. [Indonesian]

Wu SG, Bao FS, Xu EY, Wang Y, Chang Y, Xiang Q. 2007. A leaf recognition algorithm for plant classification using probabilistic neural network. IEEE International Symposium on Signal Processing and Information Technology. DOI: 10.1109/ISSPIT.2007.4458016.

Ye M, Zhu X, Gao P, Jiang L, Wu R. 2020. Identification of quantitative trait loci for altitude adaptation of tree leaf shape with Populus szechuanica in the Qinghai-Tibetan Plateau. Front Plant Sci 11: 632. DOI: $10.3389 /$ fpls.2020.00632. 